\title{
Art and Nihilism at the Dawn of the Twentieth Century
}

\author{
Esteban Andrés Sanchez Quintana \\ Doctorate in Language and Culture. U.P.T.C \\ Tunja, Colombia \\ Email: estebandresanchez2 [AT] gmail.com
}

\begin{abstract}
In this text we will deal with some nuances of the relationship between nihilism and art in the context of the cultural crisis of the early twentieth century. To carry out this task, the following approach is proposed: first, some generalities of nihilism are established. Second, the perspective of Nietzsche is outlined, he is the one who detects that the cause of the devaluation of values has its origin in the Platonist tradition of the Western thought, proposing that, in order to overcome this situation, it is necessary to transvalue values towards a new direction. Next, we seek to reflect how nihilism took over as a crisis of civilization at the beginning of the twentieth century, to do this we will review some perspectives of artists and men of letters who developed their work in this era. Finally, a conclusion is proposed.
\end{abstract}

Keywords-Nihilism, Art. crisis, life.

\section{INTRODUCTION}

This text supports Volpi's ${ }^{1}$ definition of nihilism, that is: "the situation of uncertainty and precariousness" in which the contemporary man, which is "similar to that of a traveler who for a long time has walked on an ice surface, but with the thaw, warns that the ice cover begins to move and starts tearing into thousands of sheets. The surface of traditional values and concepts is shattered, and continuing the path is difficult".

Thus, from the image suggested by the Italian philosopher, nihilism is interpreted as referring to the destruction of the "floor" of the values on which, traditionally, all humanity was founded and guided. In other words, nihilism is a situation of drastic disorientation in which every hierarchy of the high values that in the past governed life in the West is devalued, which indicated, the possibility of denoting that there was an order, unity of meaning of "world" and life motive.

However, if none of the above remains: Are we doomed to immense nothingness? This leads to the question: Where are these values? What are we going to build this new society on? Undoubtedly, these questions are part of the task that we have in the present age. In relation to this, it is considered that, he who could best summarize this situation, in which contemporary man equates any kind of prior value to the representation of nothingness, is Friedrich Nietzsche. For this philosopher, nihilism is the devaluation of the supreme values, such as the good and the truth, which at some point were represented by God for the human being. However, it is worth noting that, in this basic definition, there is still a loose end, a factor without which, we would not be able to stop thinking about nihilism in a superficial way. Nihilism is not only a lack; nihilism is also a need for new orders of values in the face of tiredness and tedium represented by the old traditions and their truths.

This last aspect lies in assuming new values in an "active" way that allows us to take a new step or, as Nietzsche would say in Thus Spoke Zarathustra, values related to the new life that are beyond the human being ${ }^{2}$, in which we manage to build life meanings from "old and new tables". "Here I sit and wait," says Zarathustra, "laying old broken tables around me and also new half-written ones ${ }^{3}$."

Thus, the new foundation can be in two ways, either for life or against it. Hence Nietzsche ${ }^{4}$ asserts that: "nihilism has two meanings: a) nihilism as a sign of the increasing power of the spirit: active nihilism", [which, leads him to forcefully raise new values that tend to life and love life. Y] B) nihilism as decay and retreat of the power of the spirit: passive nihilism" which is represented in those values that must be destroyed, because they do not tend to the preservation of life. On the contrary, this nihilism is sustained in weak and decadent values, characteristic of a man without strength, dangerously disenchanted with his existence.

\footnotetext{
${ }^{1}$ Volpi, Franco. El Nihilismo. Ediciones ciruela. Printed. Spain, pp. 13. 2007

${ }^{2}$ Nietzsche, Friedrich. Thus Spoke Zarathustra. Alianza Editorial. Printed. Spain, pp. 34. 1980.

${ }^{3}$ Nietzsche, Friedrich. Thus Spoke Zarathustra, pp. 273. 1980.

${ }^{4}$ Nietzsche, Friedrich. The Will to Power.: Biblioteca Edaf. Printed. Spain, pp. 452000.
} 
As we can see, with the death of God, there is the possibility of affirming life (actively) or succumbing to it (passively). The only thing we can claim, for the time being, is that there is a vacancy of truth and values that must be filled. Thus, it is inferred that nihilism is not only possible as the disappearance of traditional values, but, in the same way, it is possible from the need to "transvalue" all values"5. However, with the above we cannot yet see the complexity of this difficult situation of the devaluation of existence. Therefore, it would be absurd to attempt to equate the present approach to the deep reflection of this problem, therefore our next aspiration is to present part of the verdict of Friedrich Nietzsche, who points out that the virus of nihilism has its origin in the notion of the Western world (Platonism).

\section{APPROACH TO THE VERDICT OF NIHILISM ACCORDING TO NIETZSCHE}

\section{I}

To begin with the verdict of nihilism according to the perspective of Friedrich Nietzsche, we will take as a reference Thus Spoke Zarathustra, in particular the section "Upon old and new tables" , to interpret how nihilism, in terms of exhaustion of values, is the evidence of a disenchantment of life. A disease against which Nietzsche preaches that in order to overcome it, it is necessary to build a new order of values and, with this, erect a new and unique goal for humanity. ${ }^{6}$ In other words, the German philosopher proposes that in the face of the crisis of human values and existence, first, a new path must be proposed that enables humanity to overcome the man (the next step). In relation to the above, Nietzsche conceives that this advance would mean imposing a new will for power ${ }^{7}$ that would allow the future man to reach the "superman"8. Furthermore, he says the following: "the Man is something that must be overcome; the Man is a bridge and not a goal." 9

With the above, Nietzsche evidences through the approach of the "new goal", the need to redirect the existence in the world towards a vital direction, in which the worn and old broken tables of values represented in the ancient tradition of religion and Platonism (basis of the belief that the true "ideal" world is beyond) are transvalued. And, in turn, to give purpose to the writing of "the new tables", that is, the new meanings of world and life, where it is essential that the deposit of a new nobility ${ }^{10}$, to fight fiercely against this pessimism, which is a product of the grueling reality of bearing a useless tradition, which threatens to condemn the human being to an existence of pure ${ }^{11}$ suffering and emptiness.

As is evident, "passive" nihilism, i.e. transmundane, according to Nietzsche's perspective, is revealed in the attitude of the man resigned to an existence in the void of the nothingness. That is, for these nihilists, reality is none other than slavery, the product of a disenchantment for the search of an ideal world.

In relation to this, it is understood that the building of new values is of no use, if in them survives the old will of the nothingness that led the man to despise his existence in the world, since such end up being built as a difficulty in the struggle to impose life as the most pleasant of all goods. Following Nietzsche, the weakening of the man because of this old desire of power is such that he ended up becoming sick with indifference and, thus, this suffering led to humans without purpose, without any goal, without a "What for?" "In relation to this, Volpi ${ }^{12}$ states that:

Nihilism is, therefore, the "nonsense" that appears when the binding force of traditional responses to "What for?" of life and being is weakened, and this happens throughout the historical process in the course of which the supreme traditional values that responded to that "What for?"- God, the Truth, and the Good- lose their value and perish, generating the condition of "senselessness" in which contemporary humanity is at.

\footnotetext{
${ }^{5}$ Volpi, Franco. El Nihilismo, pp. 60. 2007. approaches to this concept when proposing that, Nietzsche in Ecce Homo, proclaims as an antithesis of the decadent man, who assumes life in a passive way, the strength and healthy conviction of man who does not resign himself only to exist, and therefore manages to "transvalue" in an "active" way of life and its values. In other words, he can tend "towards healthier concepts and values or, conversely, from the fullness and security of a rich life, look down to the secret work of the instinct of decadence: this has been my longest exercise, my true experience, perhaps the only one of which I have become a master. It is now in my hand, I have been given a hand to displace perspectives: the first reason why, perhaps, a "transvaluation of values" is possible for me»."

${ }^{6}$ Nietzsche, Friedrich. Thus Spoke Zarathustra, pp. 97. 1980.

${ }^{7}$ Nietzsche, Friedrich. Thus Spoke Zarathustra, pp. 169-170. 1980.

${ }^{8}$ Nietzsche, Friedrich. Thus Spoke Zarathustra, pp. 435. 1980, "the word "Superman", which describes a man of optimal constitution, in contrast to "modern" men, to "Good" Men, to Christians and other nihilists.""

${ }^{9}$ Nietzsche, Friedrich. Thus Spoke Zarathustra, pp. 34. 1980.

${ }^{10}$ Nietzsche, Friedrich. Thus Spoke Zarathustra, pp. 281-282. 1980.

${ }^{11}$ Nietzsche, Friedrich. Thus Spoke Zarathustra, pp. 283-284. 1980.

${ }^{12}$ Volpi, Franco. El Nihilismo, pp. 61. 2007.
} 
However, to develop the above, it is necessary to follow the approach that Volpi builds around Nietzsche's theory, regarding that the cause of current nihilism lies in the origin of the notion of the western world (Platonism). That is, it becomes necessary to look at the historical process that Volpi points out in the previous quotation, in which he points out, that at the origin of that history is also the origin of nihilism. However, what is this "burnout" that left the man without a goal?

Volpi ${ }^{13}$ argues that: "nihilism, as a history of the postulation and the progressive dissolution of the ideal world, is the other side of Platonism". To test his thesis, he elaborates a diagnosis of this logic of "decadence", from six points enunciated by Nietzsche in Twilight of the Idols. From them, the Italian philosopher Franco Volpi ${ }^{14}$ highlights as follows, how the world ended up becoming a fable:

«1. The true world, attainable by the wise, the pious, by the virtuous: he lives there, he himself is this world" (...) first phase [...] corresponds to the Platonic thought: it posits the existence of a true, supersensitive world, which, however, does not yet become a merely "ideal", "platonic" entity, but is attainable for the wise.

«2. The real world, for the moment unattainable, but promised to the wise, the pious, the virtuous" (...) In the second phase [...] the gap between the ideal world and the sensible world is opened (...) Moreover, the sensitive world is devaluated: the earthly existence is degraded to the level of appearance, of a transience (...) The human existence unfolds in the "here and now", but tends towards the "beyond". (...) Platonism becomes Platonism for the people, that is, Christianity.

«3. The real world is unattainable, improbable, impossible to promise, but as it is imagined is a consolation, a duty, an imperative". The third chapter [...] corresponds to the Kantian thought. The real world, supersensitive, is excluded from the realm of experience and has therefore been declared improbable, within the limits of mere theoretical reason. However, it is retrieved as a postulate of practical reason: still, forced to the pale existence of a mere hypothesis (...)

«4. The real world: unattainable? In any case, not reached. And as not reached, also unknown. Consequently, neither comforting, redeeming, binding: to what could something unknown bind us? » With the fourth chapter [...] phase of skepticism and metaphysical unbelief that follows Kantianism and idealism, and which can be identified with impatient positivism. As a result of the Kantian destruction of metaphysical certainties, the belief in the ideal world and in its cognoscibility is weakened (...) and as result nothing can be known about it and, strictly speaking, one cannot decide either for or against it. Such a world loses its moral-religious relevance (...) falls into indifference.

«5. The "real world"; an idea that is no longer useful whatsoever, it is no longer even binding, an idea that becomes useless and superfluous, therefore a refuted idea; Let us abolish it! » Nietzsche begins to present his philosophical perspective (...) the expression a "real world" is now placed in quotation marks. Indeed, from the moment the "real world" has been abolished, that term has no more value and is therefore suspended, placed in quotation marks.

With all the above stated up to this point, it is evident that the "supersensitive" world has been reduced to a superfluous hypothesis (product of its decadent logic). However, this logic leaves a void, in which, we can find the lack of aim. Thus the place of the "ideal" and the "world", which must be filled with a new meaning, is left unoccupied. In relation to this important topic, Volpi ${ }^{15}$ raises his last numeral of this fable about how that will was imposed on the world:

«6. We have abolished the real world: what world is left? Maybe the apparent one? [...] But no! With the real world we have also abolished the apparent".

With this last phase, Volpi interprets how Nietzsche, begins to give the signs of overcoming the said "nihilismPlatonism". However, with the above, Volpi is emphatic in asserting that this does not mean that the "sensitive world" should be suppressed, since this would have the nothingness as a consequence. Hence it is "necessary, instead, to leave the platonic horizon entirely, that is, the ontological dichotomy that implies its corresponding categories"16. It is these

\footnotetext{
${ }^{13}$ Volpi, Franco. El Nihilismo, pp. 62. 2007.

${ }^{14}$ Volpi, Franco. El Nihilismo, pp. 64. 2007.

15. Ibíd. Volpi.

${ }^{16}$ Volpi, Franco. El Nihilismo, pp. 65. 2007.
} 
categories, specifically, that show that nihilism is still a psychological need to fabricate" an organizing principle" of the world (end, unity, truth). In support of his claim, Franco Volpi ${ }^{17}$ quotes Nietzsche:

\begin{abstract}
""When it becomes clear that" it is not permissible to interpret the general character of existence neither the concept of "end", nor the concept of "unity", nor the concept of "truth"", one end up inhibiting all organizing principles and all transcendence, and admitting the world in its eternal flow as the only reality: the problem is that the latter is deprived of meaning and value. Therefore, "one cannot stand this world, but still one does not want to deny it"; "the categories "end", "unity" "being", with which we had introduced a value into the world, are again expelled from it by us, and now the world seems deprived of value"".
\end{abstract}

Finally, Franco Volpi draws attention to how this situation in which "'one cannot stand this world but still one does not want to deny it"", is what Nietzsche would call an "incomplete nihilism", which is nothing but the need to continue seeking the truth outside this world. That is, it is well understood that it is the same traditional evil of an ideal supersensitive nature (Platonism), which is now manifested in the beliefs of the modern man, in science (of the spirit and of the mechanical universe), in the political ideology (of nationalism or socialism) and, in the arts that value beauty above all (ideal). However, it is not yet clear what Nietzsche means by: "incomplete nihilism", "complete nihilism" and "overcoming of nihilism-Eternal Return"). To think about the above, the following is proposed.

\title{
II
}

Firstly, it is understood that "incomplete nihilism ", is the process in which there is a devaluation of traditional values in favor of new values, which, however, end up taking the place of the old traditions while serving as an ideal supersensitive, establishing a dilemma, since the new order that these values set is based on the habit of distinguishing between the "real" world and an "apparent" world. In relation to the above, Franco Volpi maintains that, this situation is the continuity of the problem of " faith "(psychological need of an order) and, consequently, the contradiction is evident in "[that] to bring down the old, one must still believe in something, in an ideal; one still has a "need of truth""18. That is, what Volpi highlights, following Friedrich Nietzsche, is how "incomplete nihilism" is evident in the constant necessity of truths, which in the case of modernity are represented in: 1 science, both historical positivism (associated with the sciences of the spirit) and a naturalistic explanation (represented in a causal and mechanistic universe). 2 in the political ideal, represented in the form of nationalism, chauvinism, socialism, or anarchism (the Russian, for example). And, finally, in art, in aestheticism and naturalism (The Exaltation of an ideal beauty).

On the other hand, Volpi argues that "complete nihilism" can be understood as the total destruction of the old values and their place of domination. Situation, in which one leaves, finally, the vision of a true ideal supersensitive world. Nietzsche exposes this idea, ${ }^{19}$ as follows:

He who has come to know the old origins will eventually seek sources of the future and new origins. "O my brethren, in a little while, new Peoples will arise and new springs will rush noisily into new depths. The earthquake, in fact, - blinds many wells and causes a lot of fainting: and it also brings out hidden energies and secrets. The earthquake reveals new springs. In the earthquake of old villages new springs emerge.

However, Volpi asserts that "complete" nihilism is a cycle that happens at the beginning in the form of decay and exhaustion of the spirit; that is, as "passive nihilism" represented as the unveiling of nothingness (evident in romantic poetry, Buddhism and Schopenhauer's philosophy). Subsequently, it manifests itself in the form of "active nihilism", which is at first the growth of the power of the spirit and then becomes an extreme form that destroys, like an "earthquake", all traditional values and places, where the vision of moral and truth as the ideal of the world is based ${ }^{20}$. In relation to the above, $\mathrm{Volpi}^{21}$ cites Nietzsche, to state that:

[In the beginning active nihilism becomes evident] as a sign of the "increased power of the spirit" which unfolds in the increase and acceleration of the process of destruction (...) [later will be] the extreme form of nihilism would be to submit for debate that all faith, all possession if true is necessarily false: because there is no REAL WORLD whatsoever. Therefore: an illusory perspective, whose origin is in us (we constantly having a necessity of a limited, abbreviated, simplified world) (...) that there is no truth; that there is no absolute constitution of things, a "thing in itself": this is nihilism, it is even extreme nihilism.

\footnotetext{
17 - Ibíd. Volpi.

${ }^{18}$ Volpi, Franco. El Nihilismo, pp. 66. 2007.

${ }^{19}$ Nietzsche, Friedrich. Thus Spoke Zarathustra, pp. 292. 1980.

${ }^{20}$ Nietzsche, Friedrich. Thus Spoke Zarathustra, pp. 294. 1980.

${ }^{21}$ Volpi, Franco. El Nihilismo, pp. 67. 2007.
} 
With the above, that is, with the total destruction of the traditional values, one can generate space for the new values to take a position of dominance. Volpi ${ }^{22}$ identifies this situation as "classical nihilism", nihilism that Nietzsche thought as the possibility of a "new position of values, based on the recognition of the will to power as the fundamental character of all that exists. By reopening the possibility of affirmation, nihilism overcomes its incompleteness and is accomplished." However, Volpi recognizes that "classical" nihilism was what Nietzsche claimed as his own (the first nihilist in Europe). In support of his claim, he cites the will to power, specifically the fragment "European nihilism":

It is necessary that we "think this thought in its most terrible form: existence, as it is, meaningless and objective, but inevitably returning, without an end in nothingness: "the Eternal Return." This is the extreme form of nihilism: the eternal nothingness (the lack of meaning")!

In this way it is inferred, that what Friedrich Nietzsche proposes as the overcoming of nihilism, is only possible to the extent of life being assumed as the "only" goal to be pursued, since life pursues itself. And, like a returning chaos, it requires no more order or sense than that of its own flow and its inexhaustible repetition. As Zarathustra would say to his dwarf Demon of Heaviness (The reflection of death) in the section "Of the vision and the enigma ${ }^{23 "): ~ " w a s ~ t h i s ~ l i f e ? ~}$ Fine! Once Again! »". In other words, the overcoming of nihilism occurs, in the "Eternal Return ${ }^{24}$. Proposal already developed in the aphorism 341 of The Gay Science "the heaviest load".

In short, life is that situation that only the "Superman"25" can endure as "eternal return". In this way, Nietzsche shows that the overcoming of nihilism as a disease is achieved by imposing life over the old ideals and over the will that these traditions represent. Therefore, it can be pointed out that the "eternal return" is then a "transvaluation" of all values, in which life is no longer an ideal, because one manages to abolish it, the antithesis between the real world and the apparent world and life is erected in the here and now, as the "only goal".

Now, with the above a new question arises: Was this antidote effective for humanity? Alternatively, can it be guessed that on the contrary, nihilism could not be overcome and this mutated into a process of deep crisis? To seek an answer, we propose to reflect, then, on nihilism as the cultural crisis at the beginning of the twentieth century.

\section{ART AND NIHILISM AT THE DAWN OF THE TWENTIETH CENTURY}

"I cling to my work, precisely because I know that the opportunity to paint does not come twice. Especially in my case, where a violent attack can forever destroy my ability to work"

(Vincent van Gogh)

It is paradoxical to start this text with the previous quotation. A quote in which the Dutch painter categorically denies any possibility of repetition. The paradox is established when remembering that only a few lines above the "eternal return" as a proposal to overcome nihilism was being discussed. However, as can be guessed, nihilism was not surpassed by man (nihilism today is a global evil).

Thus the early twentieth century, which received Nietzsche in absolute madness in anticipation of his death, it is also a century that begins with the advent of the severe symptoms that this delusional prophet had diagnosed, which would be represented in a coming debacle with unprecedented violence, in which the pillars that supported the powerful idea of modern and globalized man, would clash with the perspective of the relativity of life, since the latter saw with suspicion how the reason and the progress were erected against the diversity of life. In this way, the hidden face of development that was hidden behind the cultural logic of modernity begins to be felt strongly. Civilization and culture are in crisis.

The above is somewhat paradoxical, since if one thinks of the modern age, where the obscurantism of the Middle Ages was overcome and a deep distrust in faith was professed, which meant a breakthrough, man was thrown again into darkness, since his deep faith in science, economics, and politics could not triumph over nonsense and emptiness. Thus, modern ideals succumbed to their enemies, which were previously considered outdated. In this way, the reason represented in science, economics and politics were far from making Man the absolute owner of his destiny.

22 Volpi, Franco. El Nihilismo, pp. 68. 2007.

${ }^{23}$ Nietzsche, Friedrich. Thus Spoke Zarathustra, pp. 226-227. 1980. In relation to this concept, in this work, you can also see the section "The convalescent" pp. 279.

${ }^{24}$ Nietzsche, Friedrich. Thus Spoke Zarathustra, pp. 225. 1980.

25 To explain this concept, Volpi, Franco. El Nihilismo, pp. 69. 2007, quotes Martin Heidegger, who, according to Volpi, states that the "superman" "is not a prodigious being who would have greatly enhanced the capacity of normal man, but one who "surpasses" traditional man, in that he abandons the attitudes, beliefs and values proper to the latter and has the strength to create them again. The transvaluation of all values is the movement that opposes and overcomes nihilism: it defines the "Super-Man" as the one who expresses the maximum concentration of the will to power and accepts the eternal return of things." 
That is why the life of Man resulted in a new form of crisis. This, in our view, is evident in the statement by Vincent van Gogh, which is the epigraph of this text. In the modern world, sick men plunged into the despair of emptiness still prevail. The above can hint us and introduce us to the historical context we are dealing with, from which we will seek to look at nihilism in relation to the crisis of society at the dawn of the previous century. In relation to the above, De Micheli $^{26}$ says the following:

Van Gogh, Ensor and Munch: three artists, three destinies, three men united by the thread of a story, but distinct by their conscience, temperament and formative environment. In them - three who are undoubtedly among the greatest artists of their time-the signs of the crisis of the nineteenth century were manifested with particular evidence, and before others: they were signs of a European crisis. One era was ending and another was beginning. Problems of exceptional historical significance arose for nations and peoples. Other forces began to fight. The symptoms of the crisis would soon give way to the crisis itself (...) which way would the artists take? This was the question at the beginning of the century.

The above question is taken as a guide, to then think how that self-destructive "virus" of nothingness, which Nietzsche diagnosed, emerged with a renewed and very powerful strength at the beginning of the twentieth century.

\section{II}

By so many ways past, for me, for you, for us, but everything was suffered for the eternal question: what for? It is a childish question.

Only later did it become obvious to you, There are only two things: bearing

- be it sense, mania, legendyour determination: you must.

If roses, if snows, if seas, what flourished withered, there are only two things: the void and the indicated me.

(Gottfried Benn. «Destilaciones»)

And the artists, how did they react to the crisis ${ }^{27}$ ? As can be read in Benn's excerpt, for the artists, the historical evolution towards progress, the mutation of the forms of the past, and the question for the meaning or, if you will, the nonsense of life was not unfamiliar. The scenario of the plastic arts and literature of the early twentieth century was indeed affected by the shadow of nothingness that spread throughout the world. A mantle of darkness, under which works were erected in the form of protests or apologies to that reigning modern world, in which works of art and literary texts threw a veil behind which a void in the rational logic was hidden.

The new art of that time, inserted itself in the controversies of the time, showed its enthusiasm for change, stood as hope for the future, was novel, unlike any previous tradition, raised the need for various cultural, social and political renovations. Modern art, for or against industrialization, progress and machines, was critical of culture and advocated for the need of renewing traditions. In short, this art sought the emancipation of the splendor of the beautiful and again take the role of a guide, facing the impotence of reason to redeem the $\mathrm{Man}^{28}$. Thus art, at the time, hoisted the flags that sought to overcome nihilism once and for all.

\footnotetext{
${ }^{26}$ De Micheli, Mario. Las vanguardias artísticas del siglo XX: Alianza Forma. Printed, pp. 82-99. 2000.

27 - Ibid., De Micheli, explains how German Expressionism was erected as a formidable response to the cultural crisis, since in these artists and in their works, the influence of "Nietzsche " becomes evident. [And,] his brilliant, but confusing neo-romanticism, from which harsh attacks against the "values" of bourgeois society emerge, [which] influences the best writers, poets and artists of the era, from Thomas Mann to Grosz; Strindberg and Munch were also not immune to this fascination (...)".

${ }^{28}$ Volpi, Franco. El Nihilismo, pp. 83. 2007, argues that "it is not surprising that in such an atmosphere a search for alternative resources to rationality was initiated. The main and most tried was art. However, this is not new. There was a whole noble tradition that had considered the beautiful as the "splendor of the True"; even, in not too distant times,
} 
The above description is a reference to the various artistic avant-gardes of the twentieth century, which, on the one hand, assumed art as a response to the annoyance and the diffuse panorama, which implied the programmed march of modern progress towards nothingness. Moreover, others that, on the other hand, were represented the exaltation of the project of modernity as the advance that would lead humanity to a new history. In relation to this duality present in the plastic arts of the avant-garde, Fajardo ${ }^{29}$ summarizes the situation as follows:

Based on the modern "great story" of emancipation and the idea of freedom, the aesthetic avantgardes, both European and Latin American, enter the universalist and unitary project of the West, trying to influence and transform, not only the artistic, but the socio-political canons of their time. From these postulates results "their enthusiasm and their vigor", the explosion with which they manifested themselves. Thus, the idea of progress is not different to their commitments. Turning the machine-for the Futurists - into a "universal symbol and spiritual principle of the transcendent sign in historical social reality "(Subirants 1984: 46), already proclaims a state of optimism and security towards a certain Cartesian aesthetic that imposes the machine as the maximum expression of the power of the human being (...). On the other hand, in the Dadaist and surrealist vanguards, "the critical, negative, combative and iconoclastic character (...) is combined with its political dimension, of a movement turned towards the future. As an affirmation of new values, as an anticipation of a reality to be established; hence its prophetic and utopian character..."

As can be seen, the fine arts were immersed in the modern controversy of the time. Convulsion, in which the need for new values in the modern world became evident. And in this context, what role did literature play at the time of the cultural crisis? To answer, Volpi proposes to study the outstanding cases of the so-called "aesthetic-literary nihilism": Thomas Mann, Robert Musil and the aforementioned Gottfried Benn:

According to F. Volpi, Thomas Mann has two stages of relationship with the nihilism that Nietzsche prophesied and that was already seen as the crisis of civilization and culture: The first one is, when the writer, was assumed as an aristocrat humanist, exalting the values of the culture and the spirit (the nobility and aspirations of the German soul ) and in opposition, denounced the material values that civilization represented (the domination of the west by means of the myth of progress, the economy, the technique and the development). In relation to this, Volpi ${ }^{30}$ proposes that:

Beyond all contingencies, the contrast was from the foundation. Retaking Nietzsche's antithesis between the Dionysian and the Apollonian, and also the romantic and vitalist antithesis between spirit and life, Thomas Mann injected enthusiasm into the new semantics of modernity, by linking it with sovereign mastery in its many facets: the creativity of the abstract knowledge, the simplicity native to the intelligentsia, the cloudy and demonic fullness of life to the ascetic purity of rationality. Moreover: he held the primacy of the Germanic heroic spirit over the Anglo-Saxon mercantile spirit, the heroes (Helden) against the merchants (Häldler), aesthetic individualism against moral universalism, the mystical outburst against the ethical discipline, the spirit against politics (...) in short, he declared himself outside the universal civilization, the politicization of life, the mob of neo-humanist men of letters, to proclaim himself a citizen of a higher republic: that of the spirit, art, and philosophy.

Following Volpi, this opposition to civilization, so effusive in Thomas Mann, was the product of Nietzsche's influence, which led the artist to approach a conservative literature. However, in his later work, Mann takes a step back and begins to take politics more responsibly; starting to lose passion for Nietzsche's postures, to the point of stating that Nietzsche is dangerous and that taking him seriously can mean ruin. In other words, "Thomas Mann acknowledged that Nietzsche had rightly seen what was implicit in the tension between the Dionysian and the Apollonian, between instinct and reason, between life and spirit: sources of the diseases of civilization." ${ }^{31}$ However, for the author, the philosopher was entangled in a "tragic sense", which was unable to rebuild reason on new bases and thus conquer a new concept of humanity, which would satisfy the needs of the life of the new man. Robert Musil, who moved faster from the charm of Nietzsche to discouragement, concludes with much irony in el Espíritu y experiencias (1921), that Nietzsche's work are ""notes for readers saved in the sunset of the West"".

Nevertheless, this did not prevent Musil from developing reasons related to Nietzsche's verdict in his work, as he sees nihilism as a disease. The work of this writer, made nihilism a decadence, criticism of morality and traditional values, a

romanticism had seen in art a privileged way of access to the absolute; Schopenhauer had considered it as catharsis of the will; Nietzsche, as the only metaphysical activity that life allows us, so as not to perish because before the truth".

${ }^{29}$ Fajardo, Carlos. "Las vanguardias estéticas y la posmodernidad". Universitas Humanística, vol. 52, no 52. Online; https://revistas.javeriana.edu.co/index.php/univhumanistica/article/view/9786.

${ }^{30}$ Volpi, Franco. El Nihilismo, pp. 84. 2007.

31 - Ibíd. Volpi. 
subject of elaboration from the aestheticism, and the genius and the pathologies of creativity, that is, he assumed the overcoming of nihilism through the existential experimentation of the artist.

Finally, Franco Volpi explains that the person who took Nietzschean theory to the letter was Gottfried Benn, even after the world wars (despite the change of opinion of the vast majority of Nietzsche's followers), continued to claim that he was a "gigantic figure of the German culture". What is interesting about this artist, is not his loyalty to Nietzsche, but the way he followed the trace left by the German philosopher and, from there, managed to capitalize on an art related to the Dionysian impulse of life, which was proposed from artistic creativity, "because the art produces the form, that is, the creative foreshortening that penetrates into the reality of becoming better than the metaphysical concept of truth ${ }^{32}$."

\section{CONCLUSION}

With the above, it is thought that nihilism persists as a problem of the current era, in the same way that this phenomenon frames the crisis of the previous century, that is, the verdict of Nietzsche prevails as a valid theory to think about culture. On the other hand, art can be assumed as a point of analysis of the emptiness of the previous century, that is to say, one can understand the culture of the period from the expressions of art since there it is notorious, among other things, the dominant values of a society, which as Benn would argue it is the art that "penetrates" the reality, as it stands before our eyes, as a possibility of interpretation of the history, the values and experiences of existence in an era characterized by nihilism ${ }^{33}$.

What did the above mean? Simply, that the art masterpiece is a true possibility, to think of the "age in which nihilism is at its best" ${ }^{34}$. Now, this conclusion would open the question: what was, or is, the response of art in the development of the crisis of nothingness in the rest of the twentieth century or, at the beginning of the present century? To answer this question, another text is needed.

\footnotetext{
${ }^{32}$ Volpi, Franco. El Nihilismo, pp. 86. 2007.

${ }^{33}$ Volpi, Franco. El Nihilismo, pp. 187. 2007. Argues that: "nihilism represents more than just a stream of contemporary thought or a somber adventure of its intellectual avant-guards. It is not necessary to follow Nietzsche to recognize that his ghost is lurking a bit everywhere in any culture of our time. Nor can we think, with Heidegger, that nihilism is the very event of Western history."

34 Ávila, Manuel. "De la metafísica de la música a la música en tiempos posmetafísicos o la música y el nihilismo". Revista cuestiones de filosofía. U. P. T. C Vol.1 no. 17, pp. 15-37. 2015.
} 